\title{
REVIEW
}

\section{Non-conventional hemostatic risk factors for coronary heart disease in individuals with spinal cord injury}

\author{
B Khan ${ }^{1}$, WA Bauman ${ }^{2,3,4,5}$, AK Sinha ${ }^{4}$ and NN Kahn ${ }^{2,3,4,5}$ \\ ${ }^{1}$ American University of Antigua COM, New York, NY, USA; ${ }^{2}$ Department of Veterans Affairs Rehabilitation Research and \\ Development Service, The Center of Excellence for the Consequences of Spinal Cord Injury, Bronx, NY, USA; ${ }^{3}$ Department of Medical \\ and Research Services, James J Peters Veterans Affairs Medical Center, Bronx, NY, USA; ${ }^{4}$ Department of Medicine, Mount Sinai School \\ of Medicine, New York, NY, USA and ${ }^{5}$ Department of Rehabilitation Medicine, New York, NY, USA
}

\begin{abstract}
Study design: Review.
Objectives: In subjects with spinal cord injury $(\mathrm{SCl})$, there is strong evidence for platelet hyperactivity, which may stimulate atherosclerosis and coronary heart disease (CHD). The literature was reviewed.

Background: Individuals with SCI develop premature CHD. In addition to the conventional risk factors associated with CHD, there are pathologic hematological factors involved in atherogenesis that are similar to those that have been demonstrated in individuals with diabetes, and these hematological factors might affect individuals with $\mathrm{SCl}$. One such hematological factor, platelet aggregation, is essential for the development of CHD, which results from thrombus formation in the coronary vasculature. Prostacyclin $\left(\mathrm{PGI}_{2}\right)$ is a potent inhibitor of platelet aggregation and is thought to have a beneficial role in inhibiting atherogenesis; therefore, it is possible that individuals with $\mathrm{SCl}$ have impaired $\mathrm{PGl}_{2}$ receptor function. Methods: We reviewed the literature by conducting a search using PubMed (1970-2007).

Results: Acute thrombosis is emerging as an important factor in the etiology of CHD and therefore could mediate the risk of $\mathrm{CHD}$ in persons with $\mathrm{SCl}$, in addition to previously known risk factors such as hyperlipidemia, hypertension, hyperlipidemia, diabetes mellitus and hyperinsulinemia. Because $\mathrm{PGI}_{2}$ may retard atherogenesis through its inhibitory effects on platelet function, we discuss the effects of $\mathrm{PGI}_{2}$ on platelets in persons with $\mathrm{SCl}$ in this review.

Conclusions Subjects with chronic SCl develop abnormal platelet function, resulting in the production of atherogenic and thrombogenic factors for the following reasons: (1) the $\mathrm{PGI}_{2}$ and insulin receptors on their platelets are impaired; (2) thrombin generation and platelet-derived growth factor release are elevated; (3) insulin-induced nitric oxide production by platelets is markedly impaired; and (4) a circulating antibody (immunoglobulin $\mathrm{G}(\mathrm{lgG})$ ) blocks the antithrombotic effect of both insulin and $\mathrm{PGI}_{2}$ receptors. Thus, this IgG molecule is thought to be one of the pathological mediators of the increased incidence of $\mathrm{CHD}$ in individuals with $\mathrm{SCl}$.
\end{abstract}

Spinal Cord (2011) 49, 858-866; doi:10.1038/sc.2011.33; published online 24 May 2011

Keywords: coronary heart disease; prostacyclin; insulin; antibody; platelets

\section{Introduction}

Compared with the able-bodied population, individuals with spinal cord injury (SCI) have been reported to have an increased premature mortality because of a higher prevalence of coronary heart disease (CHD). ${ }^{1,2}$ The underlying mechanism for this increased prevalence remains obscure; however, a clustering of conventional risk factors associated with CHD among individuals with SCI has been demonstrated. These risk factors include hypertension,

Correspondence: Professor NN Kahn, Department of Medical and Research Services, James J Peters Veterans Affairs Medical Center, 130 West Kingsbridge Road, Bronx, NY 10468, USA.

E-mail: nighat.kahn@med.va.gov

Received 11 August 2010; revised 10 March 2011; accepted 11 March 2011; published online 24 May 2011 hyperlipidemia (high-density lipoprotein cholesterol and high triglycerides), diabetes mellitus and hyperinsulinemia. ${ }^{3-6}$ In addition to these risk factors, active smoking ${ }^{7}$ and the male gender ${ }^{8}$ have a large role.

Despite these metabolic, gender and lifestyle risk factors, there is an alternative hypothesis for why individuals with SCI develop CHD earlier than the able-bodied population. This premise is based on the pathological factors that are directly involved in contributing to premature and accelerated atherogenesis and thromboembolization, similar to those that have been demonstrated previously in persons with diabetes mellitus. ${ }^{9-11}$ There is an increased incidence of thromboembolism secondary to trauma in the acute phase of SCI (within 6 months of injury), and this thromboembolism does not seem to be related to the pathogenesis 
of CHD in those with chronic SCI. In fact, the occurrence of thromboembolism in persons with a chronic SCI decreases to that of the non-SCI population within 6 months of injury ${ }^{5}$ and, as such, is not related to the genesis of CHD. ${ }^{11}$ However, there is strong evidence for abnormal platelet function in persons with SCI, resulting in the production of atherogenic and thrombogenic factors.

\section{General background on prostacyclin and homeostasis}

Prostacyclin $\left(\mathrm{PGI}_{2}\right)$ and thromboxane $\mathrm{A} 2$ are cyclooxygenase metabolites of arachidonic acid (an essential fatty acid obtained only from the diet) and are the major prostanoids that regulate the homeostasis of the vascular system. In individuals with ischemic heart disease, the blood concentrations of these factors are inversely proportional: when the level of $\mathrm{PGI}_{2}$ decreases, the level of TXA2 increases. ${ }^{12-17}$ Prostacyclin is a potent vasodilator and inhibitor of platelet aggregation and is produced mainly by endothelial cells. Prostacyclin exerts its effect by binding to specific membrane receptors, which are found on the platelets, heart, aorta and kidney. These $\mathrm{PGI}_{2}$ receptors are abundantly expressed on platelets. In acute $\mathrm{CHD}$, fewer of these receptors are present on the surface of platelets, but more TXA2 receptors are present. ${ }^{18}$

Low-density lipoprotein is important for maintaining a constant concentration of cellular cholesterol; it interferes with the formation of arachidonic acid, which in turn affects prostaglandin formation and has a marked inhibitory effect on PGH synthase, the key enzyme of PG synthesis essential for the inhibition of platelet aggregation. ${ }^{19}$ Thus, elevated levels of low-density lipoprotein can reduce $\mathrm{PGI}_{2}$ levels, leading to an increase in platelet aggregation.

\section{Platelets as sources of active components}

The aggregation of platelets induced by agonists such as thrombin, ADP (adenosine diphosphate), epinephrine or collagen is essential in the normal coagulation of blood and in the development of atherosclerosis and thrombosis. ${ }^{17-20}$ Aggregation of platelets by these agonists is mediated, in part, through the intracellular synthesis of $\mathrm{PGG}_{2}$ and TXA2. ${ }^{17}$ Platelet aggregation is inhibited by several autacoids, including prostanoids, such as $\mathrm{PGI}_{2}$, and $\mathrm{PGE}_{1}$ or $\mathrm{PGD}_{2} ;{ }^{18}$ blood coagulation factor $\mathrm{Xa}^{20}$ and endothelium-derived relaxing factor/nitric oxide. ${ }^{21}$ Among the prostanoids, $\mathrm{PGI}_{2}$ is the most potent inhibitor of platelet aggregation and is generally thought to have a key role in the prevention of CHD. ${ }^{22}$ $\mathrm{PGI}_{2}$ mediates its effects by binding to specific guanosine (G)-protein-coupled prostanoid receptors. ${ }^{23}$ The stimulatory $G$ proteins induce the mobilization of intracellular calcium signaling by increasing intracellular cAMP levels, whereas inhibitory $\mathrm{G}$ proteins reduce cAMP synthesis, thereby inhibiting signal transduction. ${ }^{23}$ The role of the Gi $\alpha$ gene in the pathogenesis of atherosclerosis and thrombosis has been identified. ${ }^{24}$ Disruption of the $\mathrm{PGI}_{2}$ receptor gene in mice increases susceptibility to thrombosis. ${ }^{25}$

Platelet aggregation results in the release of plateletderived growth factor (PDGF), a well-recognized mitogenic factor in the pathogenesis of atherosclerosis and a number of other diseases, as well as the induction of apoptotic cell death. ${ }^{26,27}$ Recent studies have demonstrated the conversion from subclinical to overt CHD, which might be the case in chronic SCI subjects, where the incidence of silent ischemia is significantly increased ${ }^{28}$ and is related to endothelial injury at the site of stenosis, which is caused by rupture or fissure of the atherosclerotic plaque. ${ }^{29,30}$ At the sites of endothelial injury, TXA2, ADP, serotonin, activated thrombin, platelet-activating factor and tissue factor accumulate. ${ }^{31}$

Thrombin is known to be the most potent stimulator of platelet aggregation and has an essential role in blood coagulation. It regulates both hemostasis and thrombosis. Thrombin is also a potent mitogenic agent for arterial smooth muscle cells, inducing the proliferation of human mesangial cells that induce the synthesis of mRNA encoding PDGF, a cytokine that has been implicated in atherosclerotic plaque formation. ${ }^{26,32,33}$ The platelet-specific effects of thrombin and PDGF are inhibited by $\mathrm{PGI}_{2}$ binding to specific receptors on the platelet surface through activation of adenylate cyclase and increased cAMP. ${ }^{34-36}$ This increase in intra-platelet cAMP inhibits platelet aggregation, platelet-stimulated thrombin generation and the release reaction, including the release of PDGF. ${ }^{34-38}$ Furthermore, $\mathrm{PGI}_{2}$ inhibits agonist-induced $\mathrm{Ca}^{2+}$ mobilization from intracellular stores and inhibits store-dependent $\mathrm{Ca}^{2+}$ influx, effects that are mediated by cAMP protein kinase. ${ }^{37-40}$ Consequently, $\mathrm{PGI}_{2}$ is thought to exert a beneficial effect on the prevention of atherosclerosis through its multifactorial inhibition of platelet function. ${ }^{34-36,48}$

\section{Platelets develop abnormalities after SCI}

Although there is a higher incidence of premature CHD in individuals with SCI, the underlying pathophysiological events are poorly understood. $^{28}$ Recently, Kahn et al. ${ }^{39}$ demonstrated that platelets in individuals with SCI are not hypersensitive to aggregating agonists, such as ADP, L-epinephrine, collagen or thrombin. In addition, they are not resistant to the inhibitory effects of $\mathrm{PGE}_{1} / \mathrm{PGI}_{2}$ However, the basal level of PDGF in the plasma of persons with SCI was threefold higher than the level in able-bodied individuals $^{40}\left(6.41 \pm 0.12\right.$ vs $2.15 \pm 0.12$ pg per $10^{6}$ cells $)$ (Figure 1). Furthermore, platelet-stimulated thrombin generation and PDGF release from the platelets of patients with SCI (Figures 1 and 2) were not inhibited by the $\mathrm{PGI}_{2}$ stimulated increase in cAMP formation (Table 1). Thrombin and PDGF are atherogenic mitogens and, if left uncontrolled (that is, not inhibited by the normal counter-regulatory mechanism), would be expected to accelerate the pathogenesis of premature atherosclerosis in those with SCI.

$\mathrm{PGI}_{2}$-induced inhibition of platelet aggregation has been shown to be mediated through the binding of $\mathrm{PGI}_{2}$ to its specific receptors on the platelet surface. ${ }^{34-36}$ This binding activates the membrane-bound adenylate cyclase and, thus, increases cellular cAMP levels, leading to the inhibition of platelet function and vasodilation. In studies of platelets from subjects with SCI, equilibrium binding of the tritiated probe ${ }^{3} \mathrm{H}-\mathrm{PGE}_{1}$ was, on average, consistently less than $50 \%$ of the mean control level ${ }^{41}$ (Figure 3). 


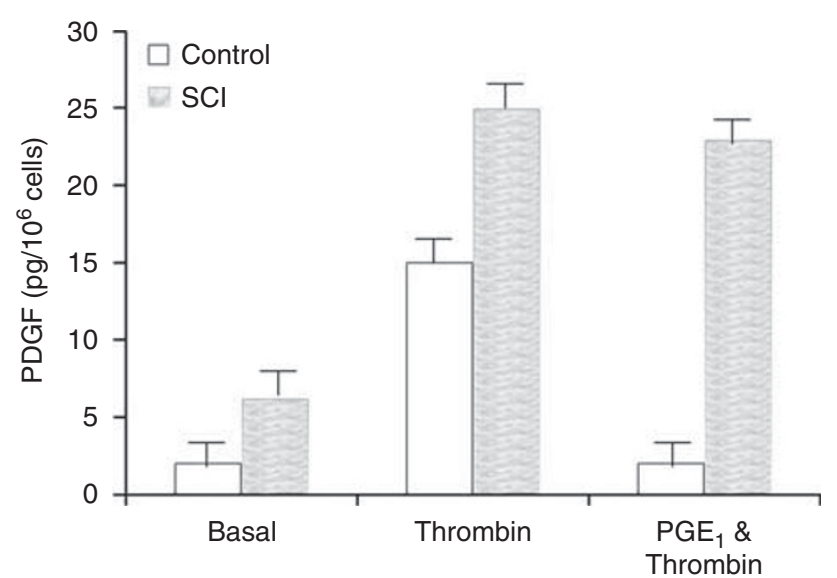

Figure 1 Effect of $\mathrm{PGI}_{2}$ on the release of PDGF in platelet-rich plasma (PRP) from control and $\mathrm{SCl}$ subjects. Platelet aggregation was studied by adding thrombin $\left(0.2 \mathrm{U} \mathrm{ml}^{-1}\right)$ to $0.5 \mathrm{ml}$ PRP in a siliconcoated cylindrical cuvette containing a Teflon-coated stirrer bar. Platelet aggregation occurred when PRP was stirred at a rate of 1200 r.p.m. at $37^{\circ} \mathrm{C}$. The reaction was stopped by adding $5 \%$ trichloro acetic acid (TCA). The supernatant was collected by centrifuging the mixture at 8000 r.p.m. for $20 \mathrm{~min}$. PDGF was determined by ELISA. Platelet aggregation was inhibited by adding $100 \mathrm{~nm} \mathrm{PGE}{ }_{1} . S C l$, spinal cord injury. Results are means \pm s.e. of six experiments, each in triplicate. ${ }^{40} * P<0.001$.

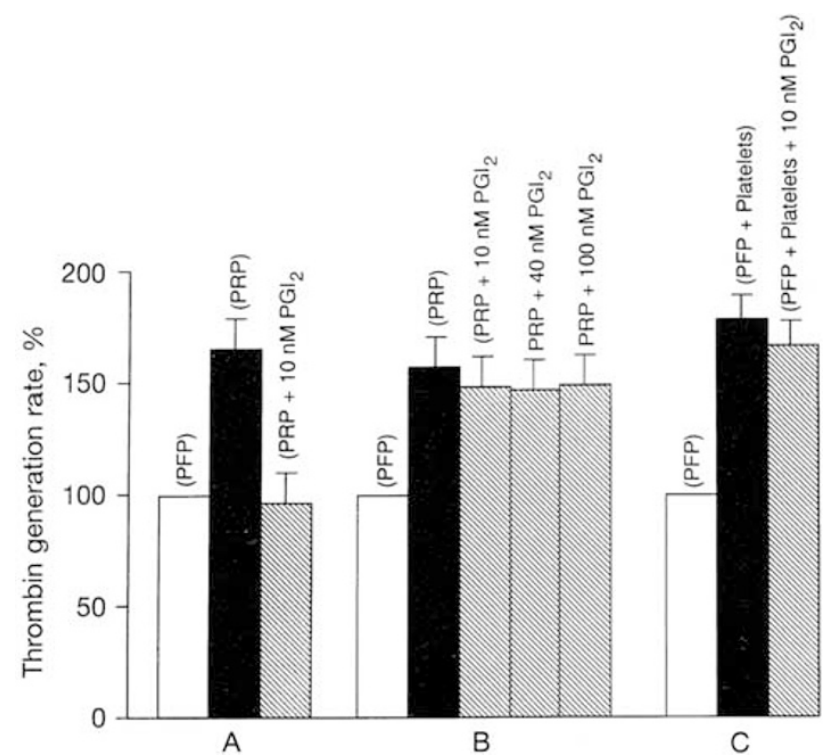

Figure 2 Effect of $\mathrm{PGl}_{2}$ on platelet-stimulated thrombin generation in platelet-rich plasma (PRP) from control and $\mathrm{SCl}$ subjects. Open bars, platelet-free plasma (PFP); black bars, PRP in the absence of $\mathrm{PGI}_{2}$; hatched bars, PRP in the presence of $\mathrm{PGI}_{2}$. (A) Normal PRP. (B) PRP from $\mathrm{SCl}$ subjects $(n=10)$. (C) Gel-filtered platelets from subjects with $\mathrm{SCl}$ suspended in plasma from controls $(n=10) .{ }^{39}$

Computer analysis of the Scatchard plot of the $\mathrm{PGE}_{1} / \mathrm{PGI}_{2}$ binding to control platelets and platelets from SCI subjects showed the presence of one high-affinity low-capacity $\mathrm{PGI}_{2}$ receptor population and one low-affinity high-capacity receptor population in both groups (Figure 4, Table 2). ${ }^{39}$ The binding of $\mathrm{PGE}_{1} / \mathrm{PGI}_{2}$ to the low-affinity receptor ( $\mathrm{Kd}$ in $\mu \mathrm{M}$ ranges) increases cAMP levels in platelets, which inhibits
Table 1 Effect of $\mathrm{PGI}_{2}$ on platelet-stimulated thrombin generation and release of PDGF in PRP from control and $\mathrm{SCl}$ subjects

\begin{tabular}{lccc}
\hline PRP & RRTG & $\begin{array}{c}\text { PDGF } \\
\text { (pg per 10 }\end{array}$ & $\begin{array}{c}\text { cells) } \\
\text { (pmol per 10 }\end{array}$ \\
\hline Normal & $2.0 \pm 0.1$ & $19.1 \pm 2.1$ & $1.84 \pm 0.65$ \\
Normal+PGI $)$ & $1.1 \pm 0.1$ & $2.5 \pm 0.3$ & $26.54 \pm 5.8$ \\
$\mathrm{SCl}$ & $1.9 \pm 0.2$ & $20.1 \pm 0.3$ & $2.1 \pm 0.43$ \\
$\mathrm{SCl}+\mathrm{PGI}_{2}$ & $2.0 \pm 0.2$ & $18.5 \pm 2.6$ & $29.3 \pm 4.34$ \\
\hline
\end{tabular}

Abbreviations: CAMP, cyclic adenosine monophosphate; PDGF, plateletderived growth factor; $\mathrm{PGI}_{2}$, prostacyclin; PRP, platelet-rich plasma; RRTG, relative rate of thrombin generation; $\mathrm{SCl}$, spinal cord injury.

PRP was treated with or without $\mathrm{PGI}_{2}(10 \mathrm{~nm})$ before RRTG was determined. ${ }^{46}$

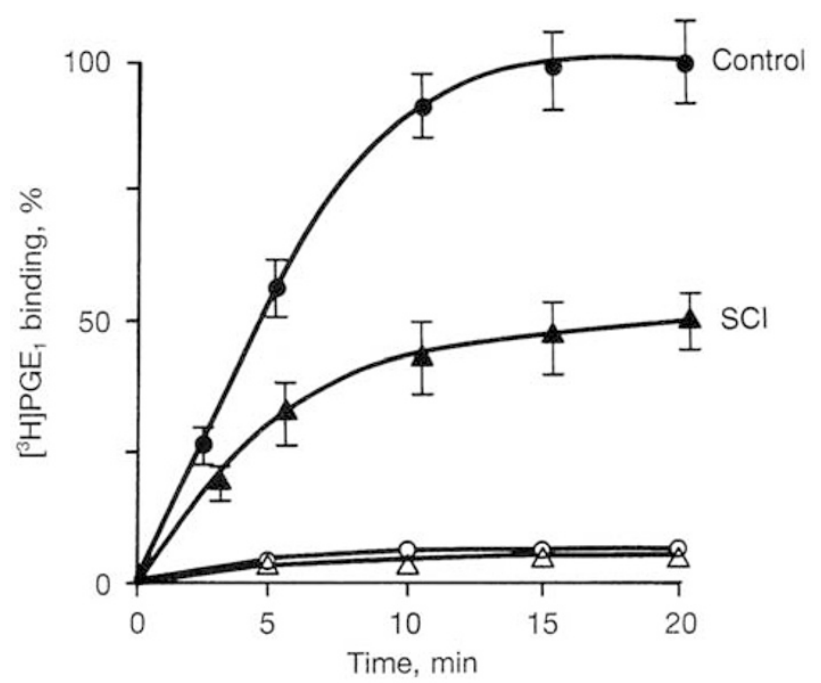

Figure 3 Time course of binding of prostaglandin $\left({ }^{3} \mathrm{H}-\mathrm{PGE} 1\right)$ to platelets from subjects with $\mathrm{SCl}$ and controls. Washed platelets were incubated with ${ }^{3} \mathrm{H}-\mathrm{PGE}_{1}(3 \mathrm{~nm})$ at $23^{\circ} \mathrm{C}$, and for different times the binding of the radioactive ligand to the control $(\bullet)$ and subjects with $\mathrm{SCl}(\boldsymbol{\Delta})$ was determined. Non-specific binding to control $(O)$ and $\mathrm{SCl}$ platelets $(\triangle)$, respectively. Results are expressed as means \pm s.e. of three experiments, each in triplicate. ${ }^{39}$

platelet aggregation. ${ }^{34,39}$ The binding of the agonist to the high-affinity receptor also increases cAMP levels, probably in a compartmentalized manner and in a smaller quantity compared with the synthesis of cAMP through low-affinity binding. ${ }^{41}$ Furthermore, the synthesis of cAMP by highaffinity prostaglandin binding is under feedback inhibition by the nucleotide itself. ${ }^{41}$ The binding of $\mathrm{PGI}_{2}$ to its highaffinity, but not to its low-affinity, receptors is physiologically more important because the plasma level of $\mathrm{PGI}_{2}$, even when stimulated, is in the nм range (3-15nm) and corresponds only to the $\mathrm{Kd}$ of the high-affinity receptors ( $\sim 9 \mathrm{~nm}$ ). The binding of $\mathrm{PGI}_{2}$ to its high-affinity, but not to its low-affinity, receptors is inhibited by guanosine-5' - triphosphate. ${ }^{39}$ In individuals with SCI, it has recently been shown that inhibition of platelet aggregation by increasing cAMP through low-affinity $\mathrm{PGI}_{2}$ receptor binding exclusively failed to inhibit PDGF release or platelet-stimulated thrombin generation, $^{39}$ and this failure was postulated to be related to the loss of high-affinity $\mathrm{PGI}_{2}$ receptors (Table 4). 


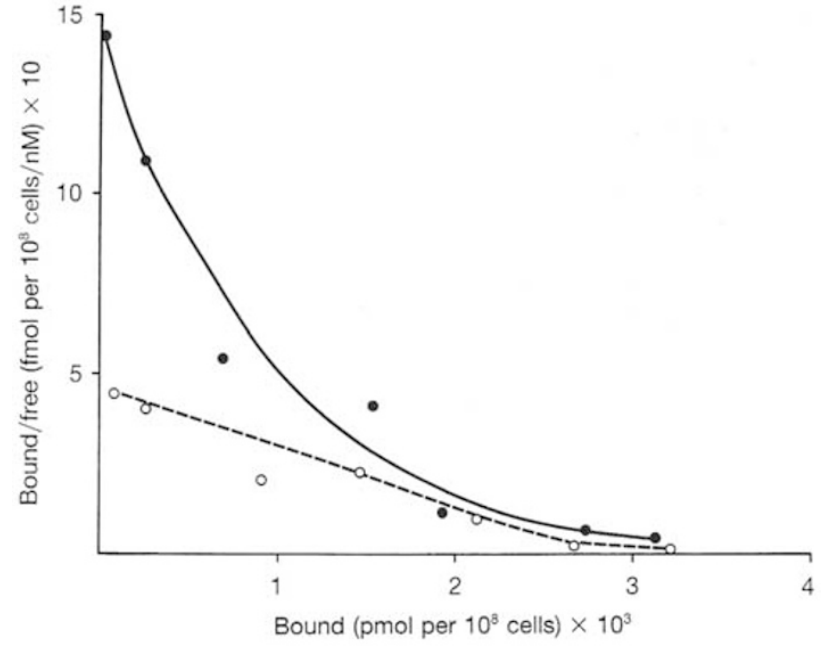

Figure 4 Scatchard plot of the binding of ${ }^{3} \mathrm{H}-\mathrm{PGE}_{1}$ to platelets from subjects with $\mathrm{SCl}$ and controls. The Scatchard plot represents nine experiments performed in each of the two groups. Each point in the plot is the average of three experiments: $(O)$ subjects with $\mathrm{SCl}$; (๑) control subjects. $^{42}$

Table $2{ }^{3} \mathrm{H}_{-} \mathrm{PGE}_{1}$ binding to platelets from $\mathrm{SCl}$ and controls

\begin{tabular}{lcclll}
\hline Platelets & \multicolumn{2}{c}{ High affinity } & & \multicolumn{2}{c}{ Low affinity } \\
\cline { 2 - 3 } & Receptor $\left(\mathrm{n}_{1}\right)$ & $K d_{1}(n M)$ & & Receptor $\left(\mathrm{n}_{2}\right)$ & $K_{2}\left(\mu d_{2}(\mu)\right.$ \\
\hline Control & $172 \pm 23$ & $8.11 \pm 2.8$ & & $1772 \pm 226$ & $1.01 \pm 0.30$ \\
SCl & $43 \pm 10$ & $6.3 \pm 1.91$ & & $1820 \pm 421$ & $1.22 \pm 0.23$ \\
\hline
\end{tabular}

Abbreviations: $\mathrm{PGE}_{1}$, prostaglandin $\mathrm{E}_{1} ; \mathrm{SCl}$, spinal cord injury.

Binding of ${ }^{3} \mathrm{H}-\mathrm{PGE}{ }_{1}$ was analyzed according to Scatchard. ${ }^{39}$

\section{Novel immunoglobulin G (IgG) identified in SCI}

Platelets from subjects with SCI had markedly decreased numbers of high-affinity $\left(\mathrm{Kd}_{1}\right) \mathrm{PGI}_{2}$ binding sites when compared with controls ( $n_{1}=172$ vs 43 sites per platelet), with no effect on the low-affinity binding sites (Table 2 ). To determine whether the decreased number of high-affinity $\mathrm{PGI}_{2}$ binding sites in platelets from SCI subjects was a consequence of abnormalities of the platelets that developed after injury or whether impairment was a consequence of the presence of inhibitors in the circulation, washed platelets from individuals (non-SCI) were incubated in plasma from SCI subjects and ${ }^{3} \mathrm{H}-\mathrm{PGE}_{1}$ binding was determined. ${ }^{42}$ Incubation of non-SCI platelets in plasma from SCI subjects resulted in the inhibition of binding of ${ }^{3} \mathrm{H}-\mathrm{PGE}_{1}$ to highaffinity binding sites $(170 \pm 32$ vs $23 \pm 8$ sites per platelet) (Table 3).

Such treatment of normal platelets resulted in the failure of $\mathrm{PGE}_{1} / \mathrm{PGI}_{2}$ to inhibit platelet-stimulated thrombin generation and PDGF release, without any impairment of the stimulation of cAMP formation or $\mathrm{PGI}_{2}$-induced inhibition of platelet aggregation. ${ }^{39}$ These results suggested the presence of an inhibitor(s) in the plasma of patients with SCI that is capable of partial impairment of platelet-PGI interactions and that consequently resulted in partial blockade of the $\mathrm{PGI}_{2}$ effects on platelets ${ }^{39}$ (Table 3).
Table 3 Effect of incubation of control platelets with IgG eluate from $\mathrm{SCl}$ plasma on the binding of ${ }^{3} \mathrm{H}-\mathrm{PGE}_{1}$ to prostacyclin receptors compared with prostanoid binding to $\mathrm{SCl}$ platelets

\begin{tabular}{|c|c|c|c|c|c|}
\hline \multirow[t]{3}{*}{ Platelets } & \multirow[t]{3}{*}{ Treatment } & \multicolumn{4}{|c|}{$P G E_{1} / P G I_{2}$ receptors } \\
\hline & & \multicolumn{2}{|c|}{ High affinity } & \multicolumn{2}{|c|}{ Low affinity } \\
\hline & & $K d_{1}(n M)$ & $\begin{array}{l}\mathrm{n}_{1} \text { sites } \\
\text { per cell }\end{array}$ & $K d_{2}(\mu \mathrm{M})$ & $\begin{array}{l}\mathrm{n}_{2} \text { sites } \\
\text { per cell }\end{array}$ \\
\hline Control & Buffer & $9.1 \pm 2.0$ & $170 \pm 32$ & $1.9 \pm 0.1$ & $1832 \pm 232$ \\
\hline Control & $\begin{array}{l}\text { IgG eluate } \\
\text { from } \mathrm{SCl}\end{array}$ & $7.2 \pm 1.1$ & $23 \pm 8$ & $1.6 \pm 0.1$ & $1740 \pm 161$ \\
\hline Control & $\begin{array}{l}\text { IgG eluate } \\
\text { from control }\end{array}$ & $8.9 \pm 0.9$ & $162 \pm 34$ & $1.8 \pm 0.3$ & $1876 \pm 138$ \\
\hline $\mathrm{SCl}$ & Buffer & $7.5 \pm 1.5$ & $40 \pm 10$ & $2.1 \pm 0.3$ & $1970 \pm 214$ \\
\hline
\end{tabular}

Abbreviations: IgG, immunoglobulin $\mathrm{G}$; $\mathrm{PGE}_{1}$, prostaglandin $\mathrm{E}_{1} ; \mathrm{PGI}_{2}$, prostacyclin; $\mathrm{SCl}$, spinal cord injury.

Platelets were isolated from either control (non-SCI subjects) and incubated with or without $\mathrm{IgG}$ isolated from $\mathrm{SCl}$ or control plasma. The binding of ${ }^{3} \mathrm{H}-\mathrm{PGE}_{1}$ to platelets was determined and analyzed by Scatchard plot. Results are expressed as means \pm s.d. of six experiments, each performed in triplicate.

$$
\begin{array}{lllllllllll}
1 & 2 & 3 & 4 & 5 & 6 & 7 & 8 & 9 & 10 & 11 \\
\text { Glu } & \text { Val } & \text { Gln } & \text { Leu } & \text { Val } & \text { Glu } & \text { Asn } & \text { Gly } & \text { Gly } & \text { Gly } & \text { Leu } \\
\text { E } & \text { V } & \text { Q } & \text { L } & \text { V } & \text { E } & \text { S } & \text { G } & \text { G } & \text { G } & \text { L } \\
\text { I } & \text { I } & \text { I } & \text { I } & \text { I } & \text { I } & \text { I } & & & & \\
\text { E } & \text { V } & \text { Q } & \text { L } & \text { V } & \text { E } & \text { S } & & & &
\end{array}
$$

Figure 5 Partial amino-acid sequence of the antibody ( $\mathrm{lgG}$ ) from SCl plasma. As illustrated, the amino-acid sequence of the antibody from SCl plasma was determined. Amino-acid identities of the heavy chain of $\lg \mathrm{G}$ (V-III region) from $\mathrm{SCl}$ plasma (in bold letters) overlapped with seven amino acids when compared with the IgG sequence in the Swiss Protein Data Base. ${ }^{42}$

Furthermore, the inhibitor has been identified by Kahn et al. as a novel $\mathrm{PGI}_{2}$ receptor antibody (IgG) that specifically blocks the high-affinity $\mathrm{PGI}_{2}$ receptors on the platelet surface, without affecting the low-affinity $\mathrm{PGI}_{2}$ receptors on the same platelet or the stimulation of adenylate cyclase (through the binding of $\mathrm{PGE}_{1} / \mathrm{PGI}_{2}$ to its low-affinity receptors on the platelet membranes). ${ }^{42}$ The partial aminoacid sequence of this IgG showed that it was a free heavychain antibody (IgG) with a molecular weight of $47 \mathrm{kDa}$ (Figure 5). ${ }^{42}$

\section{Appearance of $\mathrm{PGI}_{2}$ receptor-specific antibody after $\mathrm{SCI}$}

These high-affinity $\mathrm{PGI}_{2}$ receptors on the platelet membrane bilayers are essential for normal platelet function. ${ }^{38}$ Because it has previously been shown that the number of these receptors was decreased in subjects with SCI, the time course after acute SCI for the development of measurable amounts of this antibody specific for the $\mathrm{PGI}_{2}$ receptor was determined in a cross-sectional study. It was demonstrated that inhibition of $\mathrm{PGI}_{2}$ binding to platelets from SCI subjects paralleled the appearance of a $\mathrm{PGI}_{2}$ receptor antibody in the plasma of these subjects. This antibody was detected 
Table 4 Duration of $\mathrm{SCl}$ and its effect of on the binding of ${ }^{3}[\mathrm{H}]-\mathrm{PGE}_{1}$ to platelets from subjects with $\mathrm{SCl}$ and non-SCI

\begin{tabular}{|c|c|c|c|c|c|}
\hline \multirow[t]{3}{*}{ Platelets } & \multirow{3}{*}{$\begin{array}{c}\text { Years } \\
\text { after SCI }\end{array}$} & \multicolumn{4}{|c|}{$P G E_{1} / P G I_{2}$ receptors } \\
\hline & & $\begin{array}{l}\text { High } \\
\text { affinity }\end{array}$ & $\begin{array}{c}\text { Receptor } \\
\text { number }\end{array}$ & $\begin{array}{l}\text { Low } \\
\text { affinity }\end{array}$ & $\begin{array}{c}\text { Receptor } \\
\text { number }\end{array}$ \\
\hline & & $K d_{1}(n M)$ & $\begin{array}{l}\mathrm{n}_{1} \text { sites } \\
\text { per cell }\end{array}$ & $K d_{2}(\mu \mathrm{M})$ & $\begin{array}{l}\mathrm{n}_{2} \text { sites } \\
\text { per cell }\end{array}$ \\
\hline Non-SCl & - & $9.1 \pm 2.1$ & $172 \pm 30$ & $1.85 \pm 0.1$ & $1832 \pm 231$ \\
\hline \multirow[t]{5}{*}{$\mathrm{SCl}$} & 1 & $8.9 \pm 2.0$ & $153 \pm 15^{*}$ & $1.9 \pm 0.3$ & $1874 \pm 104$ \\
\hline & 3 & $7.2 \pm 2.0$ & $107 \pm 25^{*}$ & $1.6 \pm 0.2$ & $1790 \pm 116$ \\
\hline & 5 & $7.4 \pm 1.8$ & $40 \pm 4.1^{*}$ & $1.8 \pm 0.3$ & $1920 \pm 210$ \\
\hline & 10 & $6.8 \pm 0.7$ & $34 \pm 9.0^{*}$ & $2.2 \pm 0.3$ & $1846 \pm 183$ \\
\hline & $>10$ & $9.8 \pm 0.2$ & $32 \pm 8.0^{*}$ & $2.1 \pm 0.2$ & $1960 \pm 264$ \\
\hline
\end{tabular}

Abbreviations: $\mathrm{PGE}_{1}$, prostaglandin $\mathrm{E}_{1} ; \mathrm{SCl}$, spinal cord injury.

${ }^{*} P<0.001$ in comparisons of 1 year after injury with $3,5,10$ or $>10$ years. ${ }^{43}$ Platelets were isolated from $\mathrm{SCl}$ and non-SCl plasma. The binding of ${ }^{3}[\mathrm{H}]-\mathrm{PGE}_{1}$ to platelets was determined and analyzed by Scatchard plot. Results are expressed as mean \pm s.d. of six experiments, each performed in triplicate.

in the plasma of subjects with SCI only 1 year after injury. A progressive increase in the antibody level was observed during the first 5 years after SCI in subjects with paraplegia and quadriplegia (Table 4$).{ }^{43}$

The increase in antibody observed during the first 5 years after SCI coincides with an increase in C-reactive protein (CRP, $>3 \mathrm{mgl}^{-1}$ ) and other risk factors for CHD. Clinical studies that examined CHD risk factors in individuals with SCI (1-40 years post injury) have shown that CRP (a marker of inflammation and CVD risk) was higher in persons with SCI $\left(3.37 \pm 2.86 \mathrm{mgl}^{-1}\right)$; it is notable that CRP levels were $74 \%$ higher in those with quadriplegia $\left(4.31 \pm 2.97 \mathrm{mgl}^{-1}\right)$ than in those with paraplegia $\left.\left(2.74 \pm 2.47 \mathrm{mgl}^{-1}\right), P=002\right)$. (The clinical guidelines established by the American Heart Association for CRP state that values $>3 \mathrm{mgl}^{-1}$ correspond to a high risk of CHD). ${ }^{44}$

A study reported that individuals who had SCI of more than a year before (average time post injury: 12.8 \pm 13.45 months) had higher total cholesterol (TC; $205 \pm 36$ vs $\left.186 \pm 32 \mathrm{mg} \mathrm{dl}^{-1} ; P=0.025\right)$, higher total cholesterol TC/ high-density lipoprotein $\left(6.26 \pm 1.5\right.$ vs $5.34 \pm 1.17 \mathrm{mg} \mathrm{dl}^{-1}$; $P=0.005)$ and higher low-density lipoprotein/high-density lipoprotein $\left(4.16 \pm 1.3\right.$ vs $\left.3.57 \pm 0.9 \mathrm{mg} \mathrm{dl}^{-1} ; P=0.027\right)$ than controls. ${ }^{45}$ Other investigators have reported low concentrations of high-density lipoprotein, ranging from a mean of $27 \mathrm{mg} \mathrm{dl}^{-1}$ in SCI subjects (5 weeks up to 1 year post-injury) to $61 \mathrm{mg} \mathrm{dl}^{-1}$ in controls. Thus, the SCI group had more lipid-related risk for CHD than did the control group. ${ }^{46}$

The novel antibody that recognized only the high-affinity $\mathrm{PGI}_{2}$ receptor binding sites on platelets consequently blocked the $\mathrm{PGI}_{2}$ effect. Because both high-affinity and low-affinity binding sites for $\mathrm{PGI}_{2}$ reside on the same receptor macromolecules, ${ }^{47}$ the antibody was most likely monoclonal in origin. Because no inhibition of $\mathrm{PGI}_{2}$ binding occurred in the presence of normal plasma, and the protein was determined to be an antibody, it was concluded that the specific antibody against $\mathrm{PGI}_{2}$ receptor macromolecules developed as a consequence of SCI. The observed inhibition was not due to the IgG occurring normally in the circulation

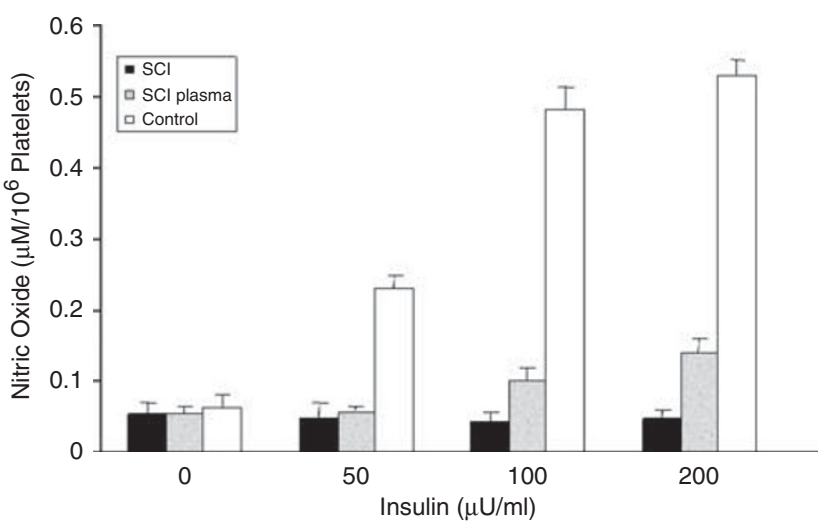

Figure 6 Insulin-induced NO synthesis in control and SCl platelets and the effect of $\mathrm{SCl}$ plasma on insulin-induced $\mathrm{NO}$ production in control platelets. Washed platelet suspension was incubated with various concentrations of insulin $\left(50-200 \mu \mathrm{U} \mathrm{ml}^{-1}\right)$. After incubation at $23{ }^{\circ} \mathrm{C}$ for $30 \mathrm{~min}$, NO production was determined. In parallel experiments, control platelets were incubated in the plasma from $\mathrm{SCl}$ individuals, and NO synthesis was determined. Each point represents the mean \pm s.d. of six experiments from six different donors, each performed in triplicate. ${ }^{4}$

(Table 4). From these observations, it was concluded that $\mathrm{PGI}_{2}$ failed to inhibit PDGF release and platelet-stimulated thrombin generation in platelets from subjects with SCI because of the presence of a $\mathrm{PGI}_{2}$ receptor-specific antibody that rendered these receptors inactive. ${ }^{42,47}$

The increase in antibody level 5 years after SCI was directly related to the decrease in binding of $\mathrm{PGI}_{2}$ to its receptor sites on platelets from both paraplegic and quadriplegic patients. Scatchard analysis (after 5 years of injury) showed a significant reduction in $\mathrm{PGI}_{2}$ receptor number in the presence of the antibody compared with controls $\left(n_{1}=34 \pm 9\right.$ vs $n_{1}=172 \pm 30$ sites per platelet, $P<0.001$ ) (Table 4). Hence, the level of the $\mathrm{PGI}_{2}$ receptor-specific antibody and the concomitant decrease in $\mathrm{PGI}_{2}$ receptor number were directly associated with the duration of injury and not the level of injury. Because the blockade of the $\mathrm{PGI}_{2}$ receptor by the antibody resulted in the impairment of $\mathrm{PGI}_{2}$ function in normal platelets, ${ }^{39,42}$ it has been suggested that these effects of $\mathrm{PGI}_{2}$ were mediated by the inhibition of $\mathrm{Ca}^{2+}$ channels through the interaction of $\mathrm{PGI}_{2}$ with its receptors on the platelet surface. $^{40}$

\section{Insulin receptor and $\mathrm{PGI}_{2}$ receptors}

Because both insulin and $\mathrm{PGI}_{2}$ may be important in the prevention of thrombosis, ${ }^{48}$ the status of insulin-induced $\mathrm{NO}$ production and the $\mathrm{PGI}_{2}$ high-affinity receptor interaction in platelets in SCI subjects was also examined. It was established that the insulin-induced NO synthesis in SCI platelets was markedly impaired because of the presence of a free heavy-chain antibody (IgG (molecular weight $47 \mathrm{kDa}$ ) in the circulation of subjects with $\mathrm{SCI}^{47}$ (Figure 6). This antibody blocked insulin receptor binding sites (40 \pm 10 vs $200 \pm 25$ receptors per platelet, with and without IgG, respectively), without affecting the dissociation constant of 


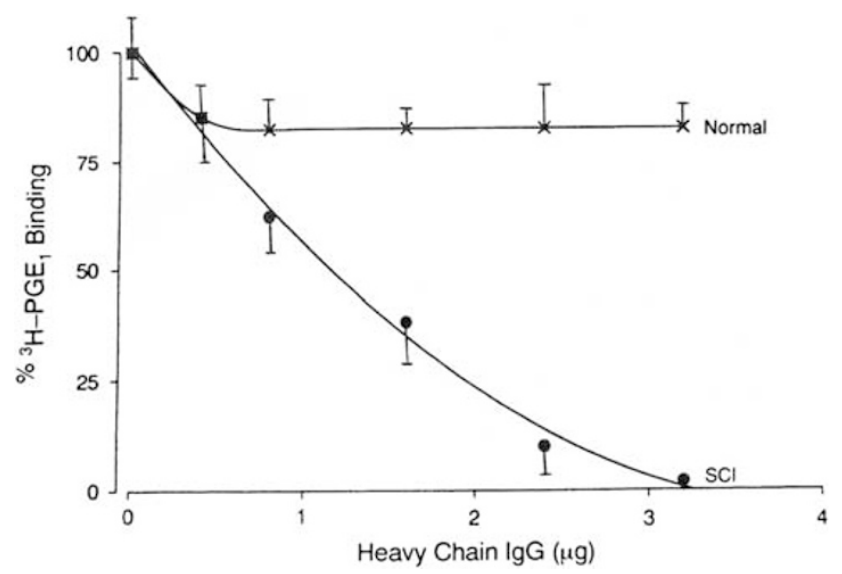

Figure 7 Inhibition of ${ }^{3} \mathrm{H}-\mathrm{PGE}_{1}$ binding to control platelets by $\lg \mathrm{C}$ protein identified in $\mathrm{SCl}$ plasma. Control platelets were incubated with increasing concentrations of the $\operatorname{lgG}$ protein for $3 \mathrm{~h}$ at $37^{\circ} \mathrm{C}$. After incubation, the specific binding of ${ }^{3} \mathrm{H}-\mathrm{PGE}_{1}$ was determined. $\times$, eluates from control plasma; $\bullet$, eluates from $\mathrm{SCl}$ plasma. ${ }^{42}$

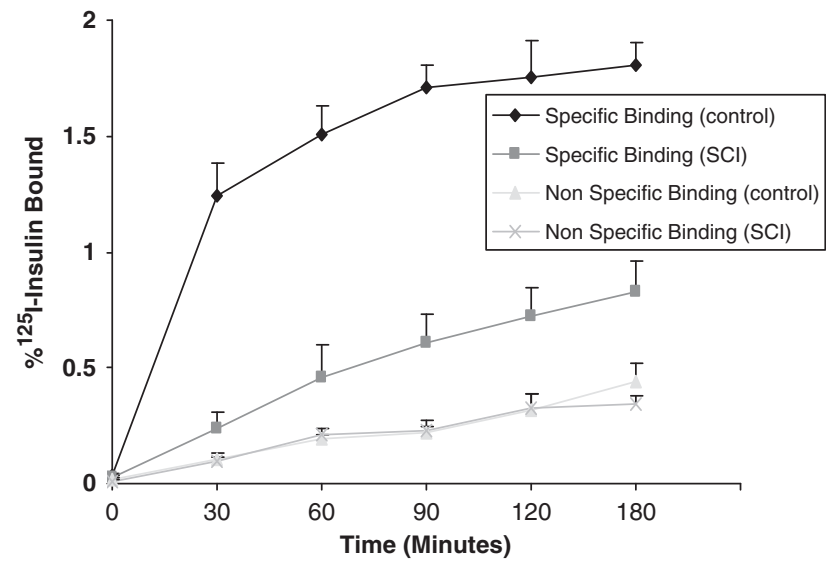

Figure 8 Equilibrium binding of ${ }^{125} \mathrm{I}$-insulin to platelets from control and $\mathrm{SCl}$ individuals. Platelets from control and $\mathrm{SCl}$ individuals were incubated with $0.14 \mathrm{pmol}$ of ${ }^{125} \mathrm{I}$-insulin at $23^{\circ} \mathrm{C}$ for $3 \mathrm{~h}$ to attain equilibrium. Specific binding and non-specific binding to platelets from controls $(\bullet, \triangle)$ and individuals with $\mathrm{SCl}(\boldsymbol{\Delta}, \mathrm{x})$ was determined. Results are expressed as mean \pm s.d. of six experiments. ${ }^{47}$

hormone binding $\left(\mathrm{Kd}_{1}=2 \times 10^{-9} \mathrm{M}\right)$ for the synthesis of NO and blocked $\mathrm{PGI}_{2}$ receptor interaction in normal platelets ( $265 \pm 41$ vs $452 \pm 56$ receptors per platelet, with and without IgG, respectively) (Figures 7 and 8). ${ }^{47}$ Because the presence of the antibody could block the antithrombotic effect of both insulin and $\mathrm{PGI}_{2}$, the antibody was thought to be one of the pathological mediators for the increased incidence of CHD in SCI individuals (Table 5). The cross-reactivity of the free antibody with two different receptor antigens was thought to result from the presence of several homologous regions in the amino-acid sequence of the insulin and $\mathrm{PGI}_{2}$ receptors (Table 6).

Recently, it has been demonstrated that insulin-induced NO has an insulin-like effect in stimulating glucose transport and glucose oxidation in muscles. ${ }^{49}$ The injection of NO into mice that were induced to develop diabetes mimicked the glucose-lowering effect of insulin in the control of hyperglycemia. ${ }^{50}$ It was hypothesized that a similar mechanism of
Table 5 Effect of the purified 47-kDa heavy-chain portion of the IgC from $\mathrm{SCl}$ on $\mathrm{PGl}_{2}$ and insulin receptor binding sites on normal platelets

\begin{tabular}{lcccccc}
\hline Receptor & $\begin{array}{c}\text { Platelets } \\
\text { treatment }\end{array}$ & \multicolumn{2}{c}{$\begin{array}{c}\text { Dissociation } \\
\text { constant }\end{array}$} & & \multicolumn{2}{c}{$\begin{array}{c}\text { Receptor number } \\
\text { (sites per cell) }\end{array}$} \\
\cline { 3 - 4 } \cline { 6 - 7 } \cline { 6 - 7 } & & $K d_{1}(n M)$ & $K d_{2}(\mu \mathrm{M})$ & & $\mathrm{N}_{1}$ & $\mathrm{n}_{2}$ \\
\hline $\mathrm{PGI}_{2}$ & None & 9.0 & 1.1 & & $200 \pm 25^{*}$ & $1748 \pm 250$ \\
$\mathrm{PGI}_{2}$ & Antibody & 8.6 & 1.5 & & $40 \pm 10^{*}$ & $1832 \pm 280$ \\
Insulin & None & 1.7 & 0.9 & & $452 \pm 56^{+}$ & - \\
Insulin & Antibody & 2.3 & 1.2 & & $265 \pm 41^{+}$ & - \\
\hline
\end{tabular}

Abbreviations: IgG, immunoglobulin $\mathrm{G}$; $\mathrm{PGI}_{2}$, prostacyclin; $\mathrm{SCl}$, spinal cord injury.

$* P<0.001$.

${ }^{+}$Insulin receptor numbers compared before and after addition of antibody. Washed platelet suspension $\left(10^{8} \mathrm{cell} \mathrm{m}^{-1}\right)$ from normal volunteers was incubated with the purified antibody $\left(0.1 \mathrm{mg} \mathrm{ml}^{-1}\right)$ for $1 \mathrm{~h}$ at $23^{\circ} \mathrm{C}$. The binding of ${ }^{3} \mathrm{H}_{-} \mathrm{PGE}_{1}$ (as a stable probe for $\mathrm{PGI}_{2}$ receptor) and ${ }^{125}$-insulin to their respective receptors were determined and the binding characteristics were analyzed by Scatchard plot. Values are mean \pm s.d.; $n=6$.

Table 6 Alignment of prostacyclin and insulin receptor protein sequence

\begin{tabular}{lccc}
\hline Receptor & Sequence & \% Identity & Residues overlap \\
\hline Prostacyclin & $1-14$ & 50 & 14 \\
Insulin & $99-113$ & & \\
Prostacyclin & $15-32$ & 33.3 & 18 \\
Insulin & $332-344$ & & 23 \\
Prostacyclin & $33-55$ & 41.2 & \\
Insulin & $401-423$ & & 71 \\
Prostacyclin & $56-122$ & 67.7 & 10 \\
Insulin & $485-555$ & & \\
Prostacyclin & $123-132$ & 31.8 & 14 \\
Insulin & $575-619$ & & \\
Prostacyclin & $133-146$ & 38.5 & 21 \\
Insulin & $755-780$ & & \\
Prostacyclin & $147-167$ & 36.4 & 23 \\
Insulin & $889-919$ & & 30 \\
Prostacyclin & $168-190$ & 37.5 & 59 \\
Insulin & $975-1040$ & & \\
Prostacyclin & $191-220$ & 28.6 & 38 \\
Insulin & $1072-1120$ & & \\
Prostacyclin & $221-279$ & 45.5 & \\
Insulin & $1121-1196$ & & \\
Prostacyclin & $280-317$ & 42.9 & \\
Insulin & $1210-1280$ & & \\
Prostacyclin & $318-386$ & 50 & \\
Insulin & $1281-1360$ & & \\
\hline
\end{tabular}

impaired NO production in the presence of this antibody may contribute to glucose metabolism disorders in SCI patients.

However, whether the systemic development of the antibody against $\mathrm{PGI}_{2}$ /insulin receptors is etiologically related to the increased incidence of CHD in SCI subjects remains to be established. Studies in SCI subjects of different age groups indicated that the increased incidence of CHD was statistically significant at least 1 year after SCI. ${ }^{43-46}$ As demonstrated, the presence of the $\mathrm{PGI}_{2}$ receptor-specific antibody in the circulation became apparent 1 year after an SCI, which could be related to the impairment of signal transduction of $\mathrm{PGI}_{2}$ receptors on platelets (Table 1); this has been related to the control/prevention of atherosclerosis by $\mathrm{PGI}_{2} \cdot{ }^{34}$ 
The presence of this antibody, albeit only the heavy-chain portion of IgG molecule, in the circulation of chronic SCI subjects could be a pathophysiological mediator of the development of premature CHD in these individuals. On the one hand, this antibody would be expected to stimulate platelet aggregation through increased thrombin generation, PDGF release and the regulation of $\mathrm{Ca}^{2+}$ channels by blocking high-affinity $\mathrm{PGI}_{2}$ receptors on the platelet surface $^{39,40}$ On the other hand, the antibody would favor systemic thrombogenesis through the inhibition of insulininduced NO synthesis in various cells, including platelets, by blocking insulin receptor binding. ${ }^{47,49-51}$

These results indicate that this antibody may act as the common pathological mediator for atherosclerosis for the various conventional risk factors and that chronic SCI itself may be considered an independent risk factor for atherosclerosis. ${ }^{52,53}$

Because the antibody inhibited the binding of ${ }^{125}$ I-insulin to its receptors, the major recognition site of this specific antibody was determined to be the $\alpha$ subunit of the insulin receptor (Table 5$).{ }^{47}$

The above results demonstrated an unusual property of a free heavy chain of the antibody molecule, which appeared in the circulation after SCI and recognized two different wellknown antigens, that is, the receptors for both insulin and $\mathrm{PGI}_{2}$ on the platelet surface. The existence of such an antibody (or one of its subunits) that recognizes two different receptors has not been reported previously. Therefore, the antibody was capable of simultaneously inhibiting and interrupting the transduction of messages by both insulin and $\mathrm{PGI}_{2}$ in the inhibition of platelet aggregation. This antibody may have an important role in thrombogenesis as a result of increased platelet aggregation, thrombin generation, and PDGF release and decreased NO production, as well as decreased glucose transport and its metabolic consequences (such as diabetes mellitus, dyslipidemia, dysregulation of blood coagulation and fibrinolysis) that are associated with atherosclerosis. ${ }^{47}$

\section{Similarity of the insulin and $\mathrm{PGI}_{2}$ receptors}

To understand whether this unusual cross-reactivity of the IgG free heavy chain with the insulin and $\mathrm{PGI}_{2}$ receptors was related to the similarity in the conformation of the protein structure of these two receptor molecules, the amino-acid sequences of these two proteins were compared using the amino-acid sequence data bank and computer-assisted alignment. ${ }^{47}$ The alignment analysis illustrated the presence of several homologous regions in these two receptor molecules (Table 6).

The antibody partially impaired $\mathrm{PGI}_{2}$ receptor function in normal platelets and was found in patients with SCI and in patients with other conditions that are known to increase the risk of CHD (for example, hypertension, hyperlipidemia, diabetes mellitus, hyperinsulinemia and a past or current history of cigarette smoking). As such, this antibody might act as a common pathological mediator for atherosclerosis in general because it would be expected to stimulate platelet aggregation through increased thrombin generation, PDGF release and regulation of $\mathrm{Ca}^{2+}$ channels by blocking highaffinity $\mathrm{PGI}_{2}$ receptors on the platelet surface. ${ }^{42}$
Despite the fact that the $\mathrm{PGI}_{2}$ receptor-specific antibody could be pathophysiologically related to the development of CHD in subjects with SCI, the nature of how the instigator, developed as a consequence of SCI, elicited the synthesis of the antibody that is present in the circulation is not known. However, as reported by other investigators, SCI might result in the production of various cytokines, including IL-17 and $\mathrm{TNF}^{52,53}$ Previously, it has been reported that cytokines induce the systemic overproduction of autoantibody. ${ }^{54,55}$ In this context, the production of $\mathrm{PGI}_{2}$ receptor-specific antibody might be called possibly, in part, an 'auto-immune' condition proved by injury to the spinal cord or related to secondary inflammatory conditions, such as, chronic pressure ulcers and/ or low grade infections of the bladder or respiratory tract.

\section{Conclusions}

Individuals with a chronic SCI have been reported to develop CHD at an early age. The etiology of this accelerated CHD, as suggested by the literature, seems to be multifactorial. Hemostatic significance has been discussed in this review. There is strong evidence for abnormal platelet function resulting in the production of atherogenic and thrombogenic factors because individuals with SCI display the following characteristics: (1) the $\mathrm{PGI}_{2}$ and insulin receptors on platelets are impaired; (2) thrombin generation and platelet-derived growth factor release are elevated; (3) insulin-induced NO production in platelets is markedly impaired; and (4) the presence of a circulating antibody (IgG) blocks the antithrombotic effect of both insulin and $\mathrm{PGI}_{2}$. Additionally, the free heavy-chain portion of the IgG molecule is thought to be one of the pathological mediators for the increased incidence of CHD in individuals with SCI. With our increased understanding of the mechanisms involved in platelet dysfunction in SCI subjects, new and effective therapies can be investigated. An early aggressive approach may be beneficial in the prevention and progression of vascular diseases in SCI subjects. A possible effective treatment may be to target and upregulate the level of highaffinity $\mathrm{PGI}_{2}$ receptors and, consequently, inhibit the progression of the atherogenic potential of platelets.

\section{Conflict of interest}

The authors declare no conflict of interest.

\section{Acknowledgements}

This work was supported by the Veterans Affairs Rehabilitation Research and Development Service, Center of Excellence for the Consequences of Spinal Cord Injury (\#B4162), James J. Peters Veterans Affairs Medical Center.

\section{References}

1 Whiteneck GG, Charlifue SW, Frankel HL, Fraser MH, Gardner BP, Gerhart KA et al. Mortality, morbidity and psychosocial outcomes of person with spinal cord injury more than 20 years ago. Paraplegia 1992; 30: 617-630. 
2 DeVivo MJ, Krause JS, Lammertse DP, DeVivo MJ, Krause JS, Lammerts DP et al. Recent trends in mortality and cause of deaths in persons with spinal cord injury. Arch Phys Med Rehabil 1999; 80: 1411-1419.

3 Bauman WA, Spungen AM. Disorders of carbohydrate and lipid metabolism in veterans with paraplegia or quadriplegia: a model of premature aging. Metabolism 1994; 43: 749-756.

4 Lipman RL, Raskin P, Love T, Triebwasser J, Lecocq FR, Schnure JJ. Glucose intolerance during decreased physical activity in man. Diabetes 1972; 21: 101-107.

5 Helmrich SP, Ragland DR, Leung RW, Paffenbarger Jr RS. Physical activity and reduced occurrence of non-insulin-dependent diabetes mellitus. $N$ Engl J Med 1991; 325: 147-152.

6 Yekutiel M, Brooks ME, Ohry A, Yarom J, Carel R. The prevalence of hypertension, ischaemic heart disease and diabetes in traumatic spinal cord injured patients and amputees. Paraplegia 1989; 27: $58-62$.

7 Spungen AM, Lesser M, Almenoff PL, Bauman WA. Prevalence of cigarette smoking in a group of male veterans with chronic spinal cord injury. Mil Med 1995; 160: 308-311.

8 Stover SL, Fine PR (eds). Spinal Cord Injury: Facts and Figures. The University of Alabama at Birmingham: Birmingham, AL, 1986, p 13

9 Brach BB, Moser KM, Cedar L, Minteer M, Convery R. Venous thrombosis in acute spinal cord paralysis. Trauma 1977; 17: 289-292.

10 Perkash A, Perkash V, Perkash I. Experiences with management of thromboembolism in patients with spinal cord injury: part 1. Incidence, diagnosis and role of risk factors. Paraplegia 1979; 16: 322-331.

11 Lamb GC, Tomski MA, Kaufman J, Maiman DJ. Is chronic spinal cord injury associated with increased risk of venous thromboembolism? J Am Paraplegia Soc 1993; 16: 153-156.

12 Lasslo A (ed). Blood Platelet Function and Medicinal Chemistry. Elsevier Science Publishing Co. Inc.: New York, 1984.

13 Smitherman TC, Milam M, Woo J, Willerson JT, Frenkel EP. Elevated thromboglobulin in peripheral venous blood of patients with acute myocardial ischemia: direct evidence of enhanced platelet reactivity in vivo. Am J Cardiol 1981; 48: 395-402.

14 DeBoer AC, Turpie AGC, Butt RW, Johnston RV, Genton E. Platelet release and thromboxane synthesis in symptomatic coronary artery disease. Circulation 1989; 66: 327-333.

15 Willerson JT, Golino P, Eidt J, Campbell WB, Buja LM. Specific platelet mediators and unstable coronary artery lesions: experimental evidence and potential clinical implications. Circulation 1989; 80: 198-205.

16 Fuster V, Badimon L, Cohen M, Ambrose JA, Badimon JJ, Chesebro J. Insights into the pathogenesis of acute ischemic syndromes. Circulation 1988; 77: 1213-1220.

17 Hamberg M, Svensson J, Samuelsson B. Thromboxanes: a new group of biologically active compounds derived from prostaglandin endoperoxides. Proc Natl Acad Sci USA 1975; 74: 2994-2998.

18 Moncada S, Gryglewski R, Bunting S, Vane JR. An enzyme isolated from arteries transforms prostaglandin endoperoxidases to an unstable substance that inhibits platelet aggregation. Nature 1976; 263: 663-665

19 Das UN. Essential fatty acids and their metabolites could function as endogenous. HMG-CoA reductase and ACE enzyme inhibitors, anti-arrhythmic, anti-hypertensive, anti-atherosclerotic, anti-inflammatory, cytoprotective, and cardioprotective molecules. Lipids Health Dis 2008; 7: 37

20 Sinha AK, Rao AK, Willis J, Colman RW. Inhibition of thromboxane $\mathrm{A}_{2}$ synthesis in human platelets by coagulation factor Xa. Proc Natl Acad Sci USA 1983; 80: 6086-6090.

21 Ignarro LJ. Biosynthesis and metabolism of endothelium derived nitric oxide. Ann Rev Pharmacol Toxicol 1990; 30: 535-560.

22 Marcus AJ, Weksler BB, Jaffe EA. Enzymatic conversion of prostaglandin endoperoxide $\mathrm{H} 2$ and arachidonic acid prostacyclin by cultured human endothelial cells. J Biol Chem 1978; 253 : $7138-7141$.

23 Hata AN, Breyer RM. Pharmacology and signaling of prostaglandin receptors: multiple roles in inflammation and immune modulation. Pharmacol Ther 2004; 103: 147-166.
24 Kahn NN. Insulin-induced expression of prostacyclin receptors on platelets is mediated through ADP-ribosylation of Gi $\alpha$ protein. Life Sci 1998; 63: 2031-2038.

25 Murata T, Ushikubi F. Altered pain perception and inflammatory response in mice lacking Prostacyclin receptors. Nature 1997; 388: 678-682.

26 Cimminiello CG, Arpaia M. Platelet-derived growth factor (PDGF) in patients with different degrees of chronic arterial obstructive disease. Angiology 1994; 45: 289-293.

27 Ross R, Bowen-Pope DF, Raines EW. Platelet-derived growth factor and its role in health and disease. Philos Trans $R$ Soc Lond B Biol 1990; 327: 155-169.

28 Bauman WA, Raza M, Machac J. Tomographic thallium myocardial perfusion imaging after intravenous dipyridamole in asymptomatic subjects with quadriplegia. Arch Phys Med Rehabil 1993; 174: 740-744.

29 Falk E. Plaque rupture with severe pre-existing stenosis precipitating coronary thrombosis: characteristics of coronary atherosclerotic plaques. Br Heart J 1883; 50: 127-134.

30 Davies MJ, Thomas AC. The cause of acute myocardial infarction, sudden ischemic death and crescendo angina. Br Heart J 1985; 53: 363-373.

31 Badimon LH, Cheseboro JH, Badimon JJ. Thrombus formation on ruptured atherosclerotic plaques and rethrombosis on evolving thrombi. Circulation 1992; 86(Suppl): III74-III85.

32 Coughlin SR, Vu T, Hing D, Wheaton V. Characterization of a functional thrombin receptor. J Clin Invest 1992; 89: 351-355.

33 Shultz PJ, Knauss TC, Mené P, Abboud HE. Mitogenic signals for thrombin in mesangial cells: regulation of phospholipase $\mathrm{C}$ and PDGF genes. Am J Physiol 1989; 257(Part 2): F366-F374.

34 Kahn NN, Sinha AK. Stimulation of prostaglandin $E_{1}$ binding to human platelet membrane by insulin and the activation of adenylate cyclase. J Biol Chem 1990; 265: 4976-4980.

35 Karamouzis M, Karamouzis I, Vamvakoudis E, Ampatzidis G, Christoulas $\mathrm{K}$, Angelopoulou $\mathrm{N}$ et al. The response of muscle interstitial prostaglandin $\mathrm{E}(2)(\mathrm{PGE}(2))$, prostacyclin (2)(PGI2) and Thromboxane A(2) (TXA $(2)$ levels during incremental dynamic exercise in humans determined by in vivo microdialysis. Prostaglandin Leukot Essent Fatty Acids 2001; 64: 259-263.

36 Brüne $B$, Ullrich V. Cyclic nucleotides and intracellularcalcium homeostasis in human platelets. Eur J Biochem 1992; 207: 607-613.

37 Geiger J, Nolte C, Walter U. Regulation of calcium mobilization and entry in human platelets by endothelium-derived factors. Am J Physiol 1994; 267(Part 1): C236-C244.

38 Kahn NN, Bauman WA, Sinha AK. Insulin-induced release of platelet plasminogen activator from human blood platelets. Am J Physiol 1995; 37: H117-H124.

39 Kahn NN, Bauman WA, Sinha AK. Loss of high-affinity prostacyclin receptors in platelets and the lack of prostaglandininduced inhibition of platelet-stimulated thrombin generation in subjects with spinal cord injury. Proc Natl Acad Sci USA 1996; 93: 245-249.

40 Kahn NN. Platelet-stimulated thrombin generation and platelet derived growth factor are normalized by insulin and $\mathrm{Ca}^{2+}$ channel blockers. Am J Physiol Endrocrinol 1999; 276: E856-E862.

41 Kahn NN, Sinha AK. Inhibition of prostaglandin E1 induced activation of adenylate cyclase in human blood platelet membrane. Biochim Biophys Acta 1988; 972: 45-53.

42 Kahn NN, Bauman WA, Sinha AK. Demonstration of a novel circulating anti-prostacyclin receptor antibody. Proc Natl Acad Sci USA 1997; 94: 8779-8782.

43 Kahn NN, Bauman WA, Sinha AK. Appearance of a novel prostacyclin receptor antibody and duration of spinal cord injury. J Spinal Cord Med 2005; 28: 97-102.

44 Gibson AE, Buchholz AC, Martin Ginis KA. SHAPE-SCI research group. C-reactive protein in adults with chronic spinal cord injury: increased chronic inflammation in tetraplegia vs paraplegia. Spinal Cord 2008; 46: 616-621.

45 Demirel S, Demirel G, Tükek T, Erk O, Yilmaz H. Risk factors for coronary heart disease in patients with spinal cord injury in Turkey. Spinal Cord 2001; 39: 134-138. 
46 LaPorte RE, Brenes G, Dearwater S, Murphy MA, Cauley JA, Dietrick R et al. HDL cholesterol across a spectrum of physical activity from quadriplegia to marathon running. Lancet 1983; 1: 1212-1213.

47 Kahn NN, Bauman WA, Sinha AK. Circulating heavy chain IgG a pathologic mediator of coronary artery disease recognizes platelet surface receptors of both prostacyclin and insulin. Platelets 2003; 14: 203-210.

48 Kahn NN, Muellar HS, Sinha AK. Restoration by insulin of impaired prostaglandin $\mathrm{E}_{1} / \mathrm{I}_{2}$ receptor activity of platelets in acute ischemic heart disease. Circ Res 1991; 68: 245-254.

49 Acharya K, Battacharya S, Acharya R, Kahn NN, Sinha AK. Purification and properties of insulin activated nitric oxide synthase. Arch Biophys Biochem 2002; 109: 441-449.

50 Sinha AK, Bhattacharya S, Acharya K, Mazumder S, Bauman WA, Kahn NN. Prevention of thrombosis in vivo nitric oxide. Ind $J$ Physiol Allied Sci 1998; 52: 148-161.

51 Trovati M, Anfossi G, Massucco P, Mattiello L, Costamagna C, Piretto $\mathrm{V}$ et al. Insulin stimulates nitric oxide synthesis in human platelets and, through nitric oxide, increases platelet concentrations of both guanosine-3', 5'-cyclic monophosphate and adenosine-3', 5'-cyclic monophosphate. Diabetes 1997; 46: 742-749.

52 Wang CX, Nuttin B, Heremans H, Dom R, Gybels J. Production of tumor necrosis factor in spinal cord following traumatic injury in rats. J Neuroimmunol 1996; 69: 151-156.

53 Dong G, Ye R, Shi W, Liu S, Wang T, Yang X et al. IL-17 induces autoantibody overproduction and peripheral blood mononuclear cell overexpression of IL-6 in lupus nephritis patients. Chin Med J (Engl) 2003; 116: 543-548.

54 Davies AL, Hayes KC, Dekaban GA. Clinical correlates of elevated serum concentrations of cytokines and autoantibodies in patients with spinal cord injury. Arch Phys Med Rehabil 2007; 88: $1384-1393$.

55 Hayes KC, Hull TC, Delaney GA, Potter PJ, Sequeira KA, Campbell $\mathrm{K}$ et al. Elevated serum titers of proinflammatory cytokines and CNS autoantibodies in patients with chronic spinal cord injury. J Neurotrauma 2002; 19: 753-761. 